\title{
Android Application for Malay Kedah Traditional House
}

\author{
Ahmad Zaharuddin Sani, \\ Ahmad Sabri \\ Institute of Tun Dr. Mahathir \\ Mohamad's Thoughts, \\ Universiti Utara Malaysia, \\ Malaysia
}

\author{
Roziya Abu \\ Department of Information \\ Management, Universiti \\ Teknologi MARA Kedah, \\ Malaysia
}

\author{
Fatinah Mangsor \\ Institute of Tun Dr. Mahathir \\ Mohamad's Thoughts, \\ Universiti Utara Malaysia, \\ Malaysia
}

\author{
Syahrini Shawalludin \\ Department of Visuals Art And \\ Design, Universiti Teknologi \\ Mara, Kedah, Malaysia
}

\begin{abstract}
The main thrust of this paper is that we describe the graphic design and illustration details of a mobile application supporting the Malay Kedah Traditional House, based on open technologies such as Android. There are two type of software used for completion of the application that are Adobe Flash and Adobe Illustrator. The Adobe Flash are more focus towards its programming and interactive while the Adobe Illustrator is used to illustrate the graphic design of the Malay Kedah Traditional House. The goal was to create an easy to use, mobile, interactive and flexible including a portable Android user. Thus the project is meant to explore, reveal, reconstruct and rearrange the chronology of its history. The future improvements will include more historical building and its history to spread and share the uniqueness of Kedah's History to not just local Malaysian but also to all international tourist or historical researcher and make plans for further developments.
\end{abstract}

\section{Keywords}

Mobile application, Android, Traditional House, Kedah, Interactive, Illustration

\section{INTRODUCTION}

Malaysia is one of the South East Asia nations. Formed on 16 September 1963, it has long and cherished history way back to the Malay Sultanate of Kedah and Malacca as well as the Malay Maritime Empire of Srivijaya (Mokthar Ismail, 2013). Most ancient Malay sultanates were established near to major international trading routes i.e. sea lines. For examples, Malacca, Pahang, Acheh, Srivijaya, Mataram and Kedah were located near to an entrepot - a port, city, or other centre to which goods are brought for import and export, and for collection and distribution (Oxford Dictionaries, 2013).

Due to western colonialisation that started in 1511 with the fall of Malacca and prolonged conflicts that ensued between local people and those unwanted "guest" for hundreds of years, records of ancient Malay artifacts were lost. Fortunately, some of it is still available mostly with international libraries and archive of their trading partners and colonialists such as in the United Kingdom, Holland, Portugal, China and Iran.
Malays experience in managing their daily affairs their states was safely locked in many ancient manuscripts that available across the world. The objectives of this paper are to find, gather, arranged and record the entire artifact related to Malay and Islam, but not least, to boost self-esteem of Malaysian through historical facts and figures.

It is important for today's society and government to look back to the cherished history of our forefathers and learned something from them in order to move forwards. "Once we believe in ourselves we can risk curiosity, wonder, spontaneous delight or any experience that reveals the human spirit." (E.E. Cummings, n.d).

Currently, there are still too little application technology being used in delivering a narrative and historiography element of social science and history of a nation. State of Kedah is not exempted from face this situation. In reality, many historical and non-historical form of information on Kedah State and its society are kept in the form of writing, pictorial and oral history. Thus, this project is a brand new effort to create a variation of State of Kedah information collection forms for future generation use. Hence Androids application is chosen for this task. Androids application is a grown and become a widespread sensation form of technology among young generations. It is said to be more practical and more fascinating in providing access, sharing of information and educating public and society. This technology has been proven to be capable for delivery of text, high resolution and sophisticated visual, audio and graphic animation.

Android Application for Malay Kedah Traditional House is the 3rd phase and a continuity invention derived from a mega study project titled "Lukisan 2 Milenia Sejarah Kedah Darul Aman". These projects are a collaboration effort between IPDM, YB Aminuddin Omar-representing the Kedah Darul Aman State Government, State Museum of Kedah and Kedah State Public Library. This Androids Application for Malay Kedah Traditional House invention are produced in accordance with the original study objective namely to published Kedah State historical facts using an advance, creative and artistic technique. 
Through this form of invention production, the team wishes to spread and share the uniqueness of the Malay Kedah Traditional House and the history of the State of Kedah itself to not just local Malaysian but also to all international community members. The project's aim is to create an Android Application for Malay Kedah Traditional House to support teaching and learning, to develop new research opportunities, and above all, to make this important manuscript accessible to anyone with an interest in the subject. The objectives are to: 1 . Gather all information about Kedah Malay House Heritage. 2. To publish State of Kedah historical facts using an advance, creative and artistic technique.

\section{LITERATURE REVIEW}

Kedah Darul Aman is one of the oldest states that exist in Malaysia today, besides Pahang Darul Makmur and Johor Darul Takzim. Its history can be traced back to 630AD. In general, the history of Kedah can be grouped into two important eras; kingdoms (630AD - 1136) and sultanates (1136 - present). The starting point of sultanates era marked the beginning of Islam in Kedah.

Even though Kedah's history was not as glorious as other Malay kingdoms and sultanates such as Langkasuka (2nd 14th century), Srivijaya (7th - 13th century), Malacca (1402 1511) and Patani (1400 - 1902), its ability to absorb pressures from various local and international aggressors and still be in existence until today is worth to appreciate.

Geographical areas of the Old Kedah Sultanate Modern day Kedah is different as compared to the Old Kedah. While the former is only one of the 14 states that formed Malaysia on 16 September 1963, the latter was a maritime empire by itself.

However, the least discussed Malay ancient states in the history of modern Malaysia, is the Old Kedah. Kedah's name was wrote and pronounced differently according to varying times and reference sources. Its name in old roman alphabets is Quedah. Kadaram and Kataha were the other names of Old Kedah commonly used by traders from India (Sabri Zain, n.d). Old Kedah is the most senior state in the federation of Malaysia, due to the fact that the state maintains its existence since the second century A.D., preceding Pahang and Johor (Nasha, Nazarudin, Tarmiji \& Zulkifli, 2008). The Old Kedah can be defined as the original sovereign state of modern Kedah Darul Aman, located approximately in the middle of the Malay Peninsula's western side.

\section{METHODOLOGY}

Started with the production of a multimedia Interactive CD of the Malay Kedah Traditional House, the team moves a step forward to transform the multimedia interactive technology application to a more popular and more recognized form of technology in this period of time - Androids. The technology application process consists of several phases:
Phase 1: Information filling concept development (information content concept development)

Phase 2: Selection and software construction (software selection and development)

Phase 3: Information filling integration and software (Information content and software integration)

There are two type of software used for completion of the application that are Adobe Flash and Adobe Illustrator. Basically, Adobe Flash are more focus towards its programming and interactive while Adobe Illustrator is used to illustrate the graphic design of the Malay Kedah Traditional House. The overview of the application function are show below:

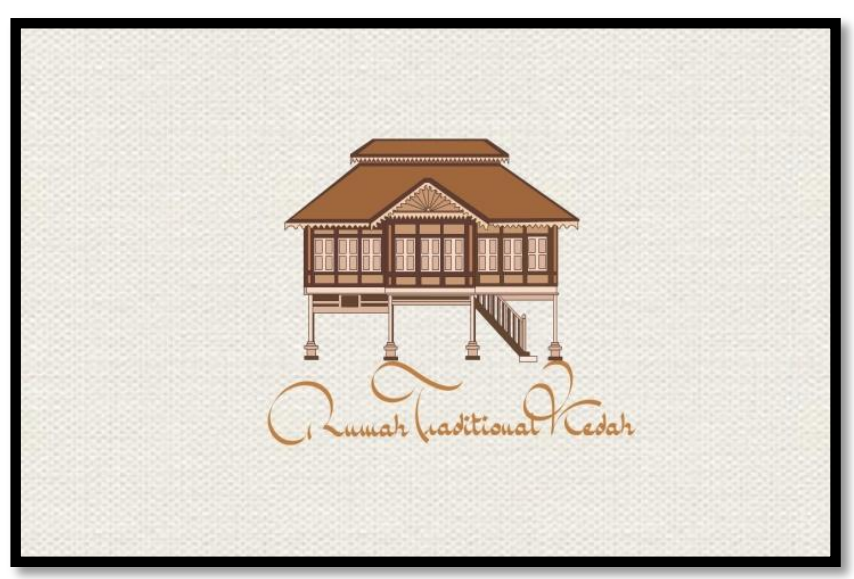

Photo 1. Main page Illustration

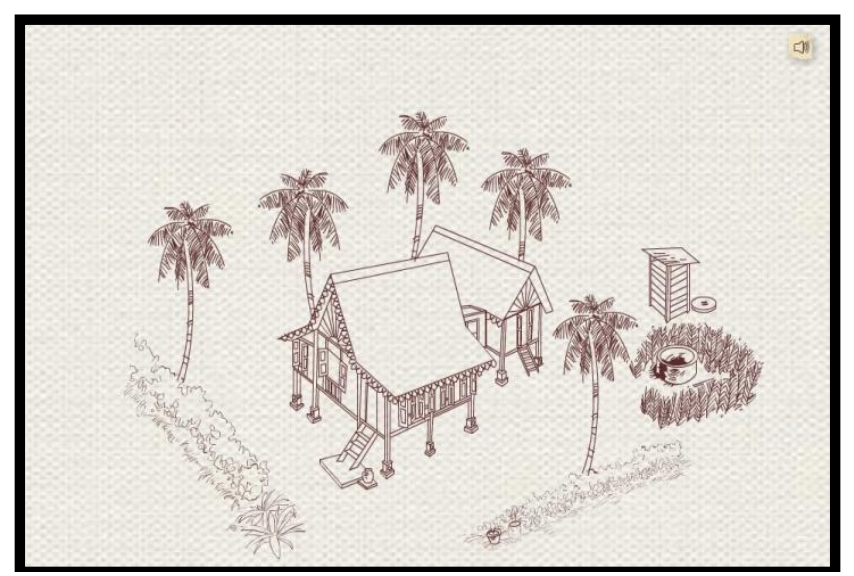

Photo 2. Simplified Illustration of the Malay Kedah Tradisional House Surroundings 


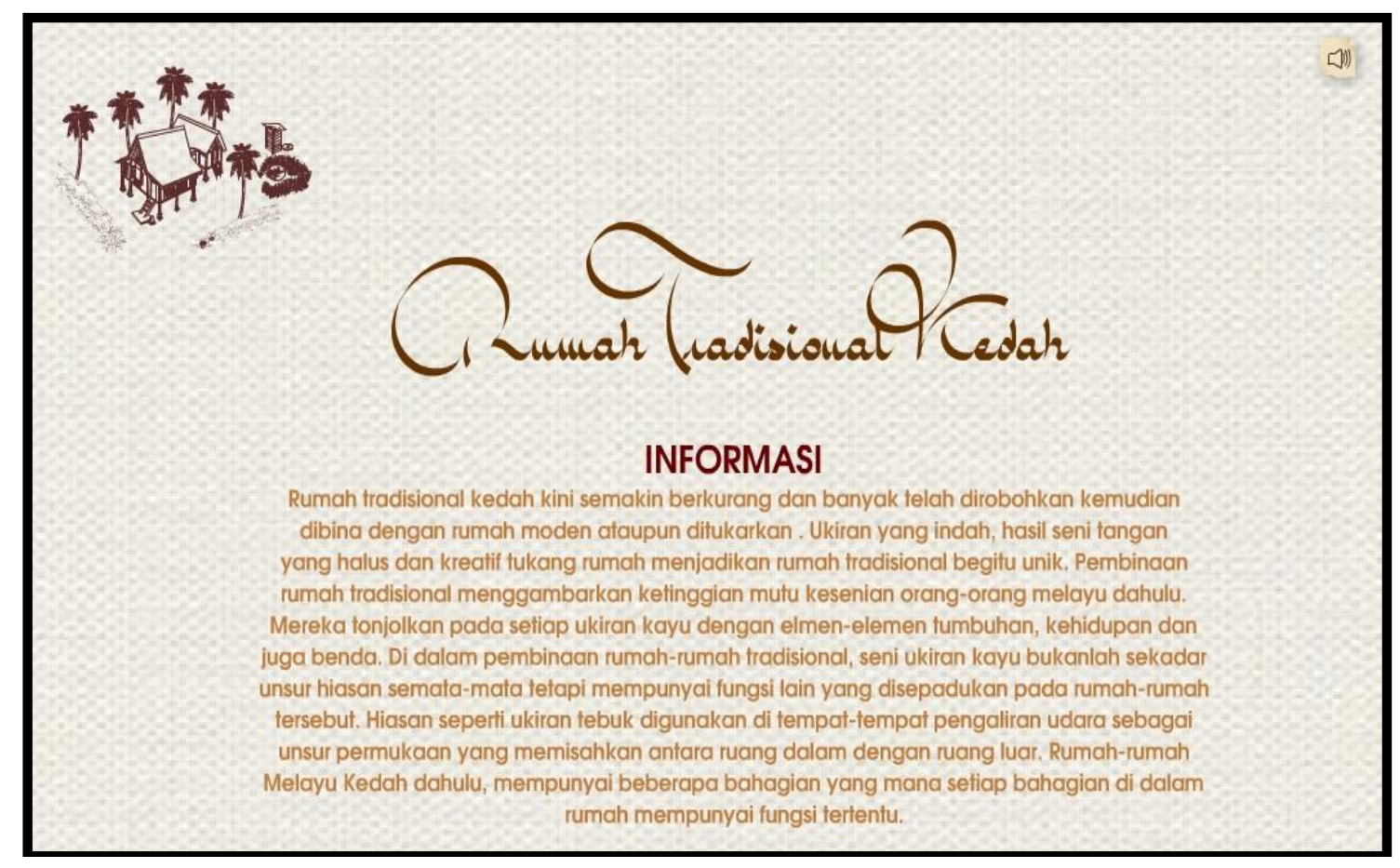

Photo 3. Malay Kedah Tradisional House Decription Information

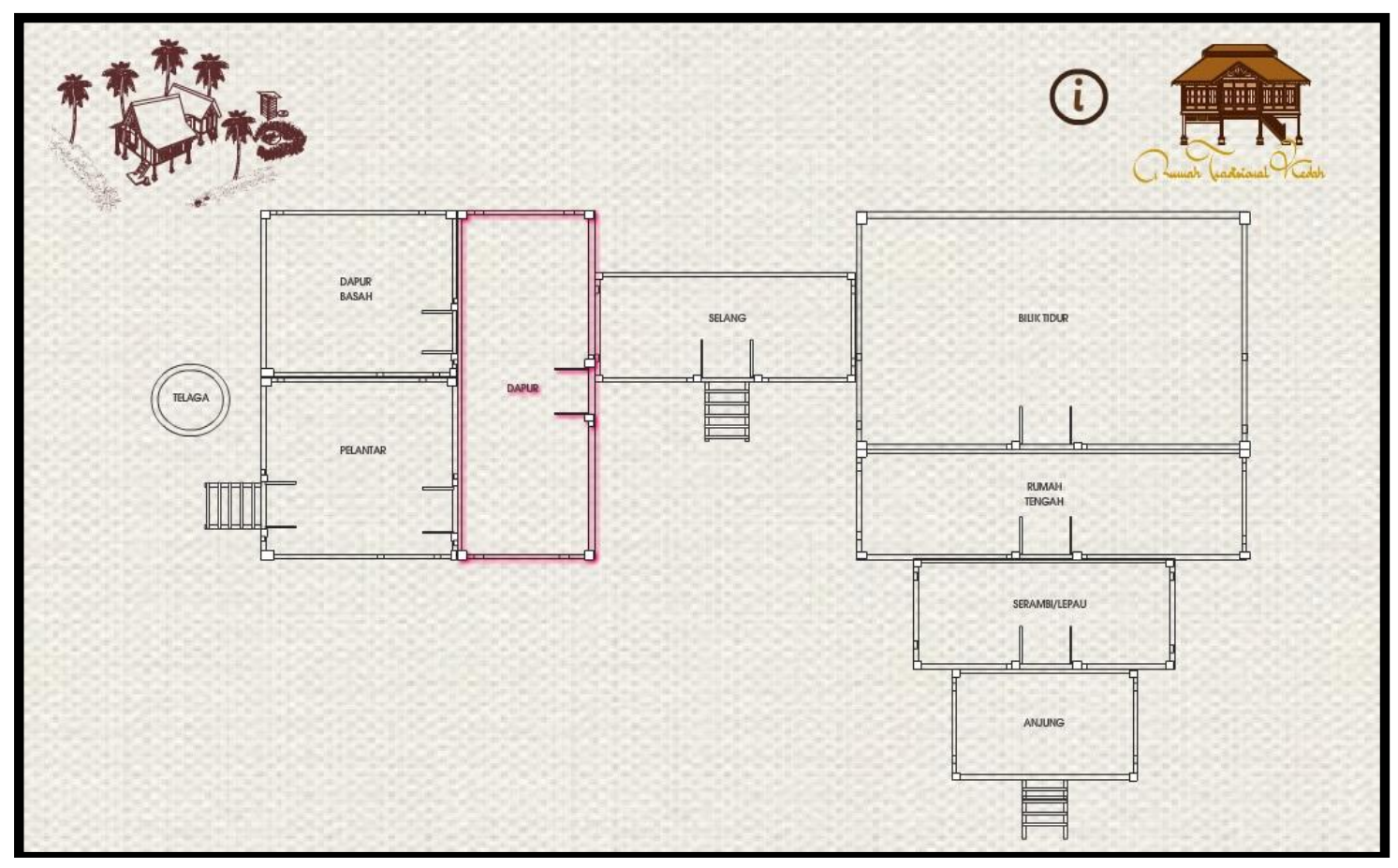

Photo 4. Malay Kedah Tradisional House Layout Illustration (e.g: Click at highlighted area; 'DAPUR') 


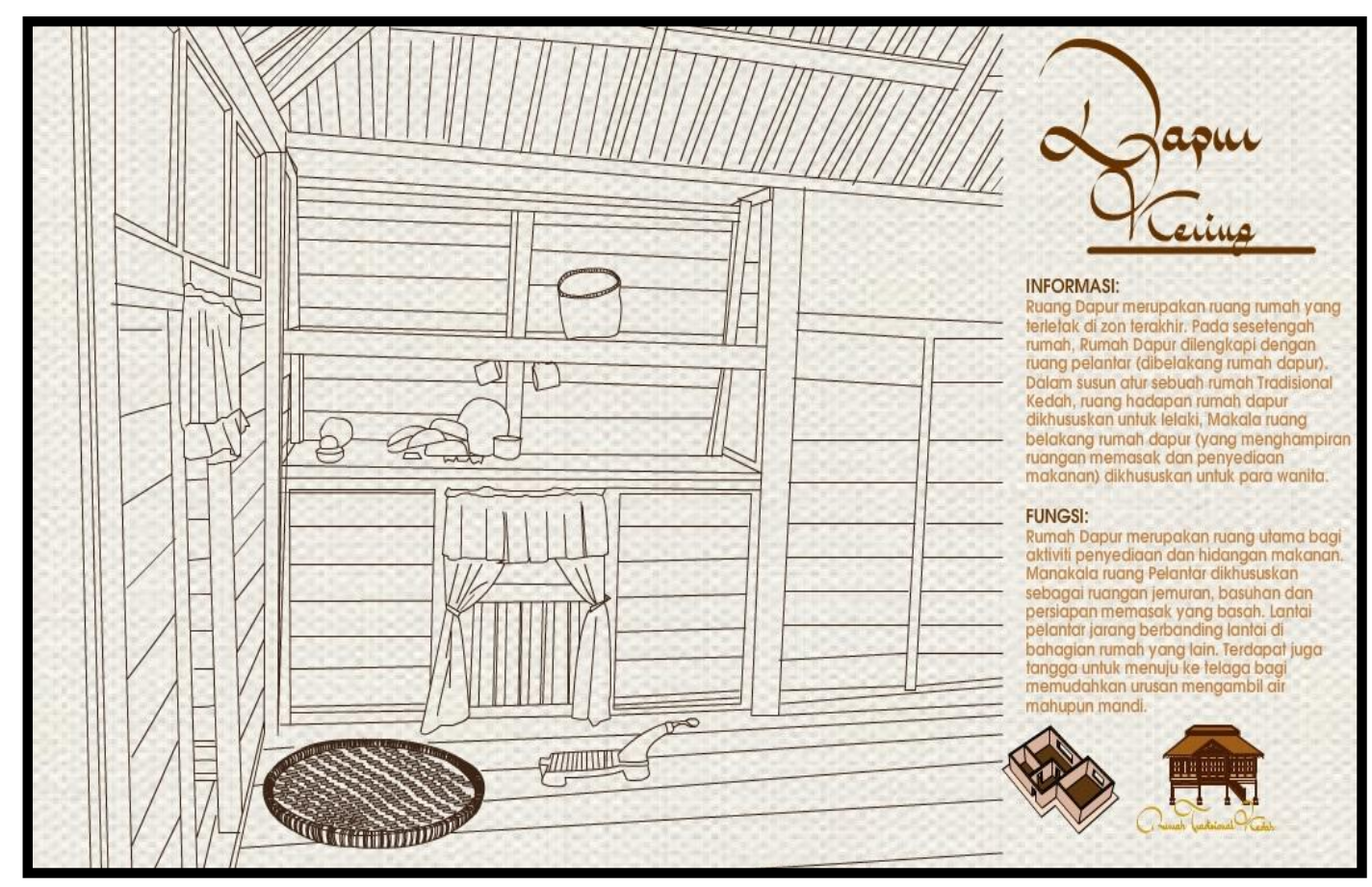

Photo 5. Malay Kedah Tradisional House ('Dapur' description)

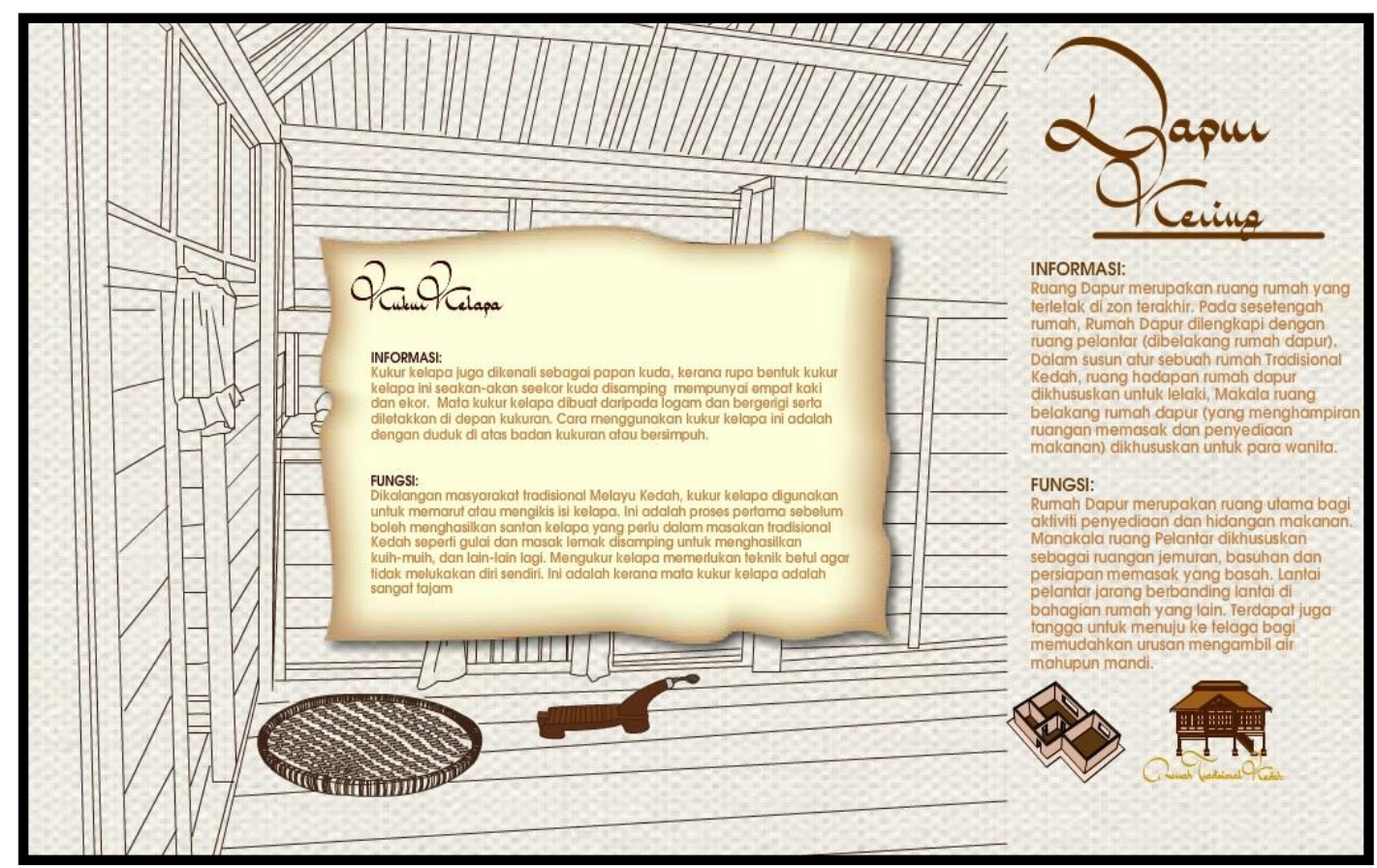

Photo 6. Tools Decription (eg: Click at highlithed objects; 'kukur kelapa')

\section{CONCLUSION}

We presented the graphic design and implementation details of an interactive mobile application supporting the Malay Kedah Traditional House illustration and details, based on open technologies such as Android.

Our goal was to create an easy to use, mobile, interactive, flexible and extensible client-server solution, including a portable Android user and a Web portal access to the content.

Thus the project is meant to explore, reveal, reconstruct and rearrange the chronology of its history.
Our future improvements will include more historical building and its history to spread and share the uniqueness of Kedah's History to not just local Malaysian but also to all international tourist or historical researcher. Other than that, it will marketability as an academic reference devices to local schools and also higher learning institution by improving to multi-language guides to help our future generation to be proud of their ancestor and made plans for further developments. 


\section{REFERENCES}

[1] Mokthar Ismail, (2013), An Insight to Malaysian Economy, 1st. edition, Bangi: Pusat Pembangunan Penyelidikan (PPP), Kolej Universiti Islam Antarabangsa Selangor (KUIS). Retrieved on September 27, 2013, from

http://www.academia.edu/4370167/An_Insight_to_Mala ysian_Economy_1st_Edition_Improved_Version_Aug_2 01

[2] Oxford Dictionaries Online, Retrieved September 26, 2013, from http://oxforddictionaries.com/definition/ english/entrep\%C3\%B4t

[3] e e cummings Quotes. (n.d.). Quotes.net. Retrieved April 10, 2014, from http://www.quotes.net/authors/e e Cummings Entrepot [Def. 1]. (n.d).

[4] Sabri Zain (n.d), Kadaram and Kataha, Sejarah Melayu: A History of the Malay Peninsula, Retrieved from http://www.sabrizain.org/malaya/early2.htm
[5] Nasha Rodziadi Khaw, Nazarudin Zainun, Tarmiji Masron \& Zulkifli Jaafar. (2008). Kemerosotan Kedah Tua: Mangsa Percaturan Politik Dan Sosioekonomi Dunia Timur (Kurun ke-13-14). Malaysia dari Segi Sejarah (Malaysia in History), 36, 52-67.

[6] Ibnu Rusydi. (2009). Sempadan sebenar Semenanjuung Melaka. Retrieved from http://ibnurusydi.blogspot.com/ 2009/09/sempadan-sebenar-semenanjung-melaka.html

[7] Mior Ahmad Noor, M.H., (2002), Kesultanan Kedah: Satu Pengenalan Ringkas Wilayah dan Jiran-jirannya, Journal of Southeast Asian Studies (JATI), Kuala Lumpur: Department of Southeast Asian Studies, University of Malaya. ISSN 1823-4127

[8] Mohd. Sukki Othman and Adi Yasran Abdul Aziz, (2012), Kedah Port Laws from the Historical and Cultural Perspectives, Kemanusiaan, 19(1), 1-16. Penang: Universiti Sains Malaysia 